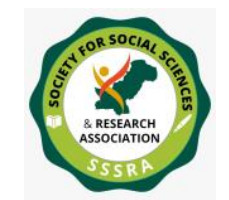

Pak. Journal of Int'L Affairs, Vol 4, Issue 3 (2021) Importance of Livestock Sector for Sustainable ...

\title{
IMPORTANCE OF LIVESTOCK SECTOR FOR SUSTAINABLE RURAL DEVELOPMENT IN BALOCHISTAN PAKISTAN
}

\author{
Dr Arslan Maqbool \\ Veterinary Officer \\ Livestock and Dairy Development Department \\ Quetta - Pakistan \\ arslanmaqbool81@gmail.com \\ Dr Abdu Rehman \\ Senior Veterinary Officer \\ Livestock and Dairy Development Department \\ Quetta - Pakistan \\ ziaratrehman@yahoo.com \\ Dr Abdul Sattar \\ Senior Veterinary Officer \\ Livestock and Dairy Development Department \\ Quetta - Pakistan \\ sattar_baloch40@yahoo.com
}

\section{ABSTRACT}

In order to judge the perceived perception of the respondents this research was conducted in Balochistan. Quantitative investigation was employed. Khuzdar and Zhob localities are randomly selected. 300 respondents were selected and 150 respondents from each district. Cluster sampling technique was applied. Findings reveal that more than half $(55 \%)$ of the respondents fell into the 41 to 60 years' age categories. While 33\% of the respondents fell into the 20 to 40 years' age categories. Vast majority of the respondents were illiterate (74\%). Majority (84\%) of the respondents was by gender male. while the remaining $16 \%$ of the respondents were female. Majority (87\%) of the respondents preferred to live in a joint family system. Chi-Square test was shown that significant $(\mathrm{p}<.05)$ association occurs between the binary variables. Following recommendations developed keeping in view study results. Vigorous futuristic marketing mechanisms about livestock advancement should be 


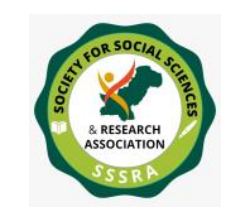

Pak. Journal of Int'L Affairs, Vol 4, Issue 3 (2021) Importance of Livestock Sector for Sustainable ...

established so that the livestock farmers could easily develop their business. Credit schemes for livestock farmers should be started in order to increase the livelihood options of the rural masses.

Keywords: Livestock sector, role, rural development, sustainable, Balochistan districts.

\subsection{Introduction}

Livestock sector is an important segment of the country 's economy. Livestock sector is contributing $60.1 \%$ farming value addition. Further, this sector is also constituting $11.5 \%$ of Pakistan's GDP in the current period. Majority of the rural communities at country level, more than eight 8 million of people and their families directly or indirectly evolved the livestock sector. On the other hand, 35 to $40 \%$ of the rural people and livelihood options are involved in this sector. It is imperative that the livestock sector in Pakistan augmented to Rs 1,505 to Rs 1,461 billion during the fiscal year of 2020 to 21 and 2019 to 20 respectively with in terms of gross value addition (GoP, 2020-21).

The government of Pakistan in this regard has converted its concentration to boost up this sector at country level so as to develop the economic growth in every developmental sphere, effective food security dynamics for every individual for ending the poverty mitigation. For effective policy implementation, the government of Pakistan is developing the effective linkages mechanism and promoting the public private partnership so as to streamlining the livestock sector. On the other hand, the government of Pakistan has also refining per unit animal productivity with in terms of humanizing animal health treatment, healthier livestock management practices or livestock animal breeding, regulatory measures in the livestock sector, value added in livestock sector, improved meat export processing zones, modern slaughterhouses development, reproduction insemination units of amenities and controlling the farms animal diseases (GoP, 2020-21).

Figure-1, Livestock overall population during the 2020-21 in Pakistan 
Pak. Journal of Int'L Affairs, Vol 4, Issue 3 (2021) Importance of Livestock Sector for Sustainable ...

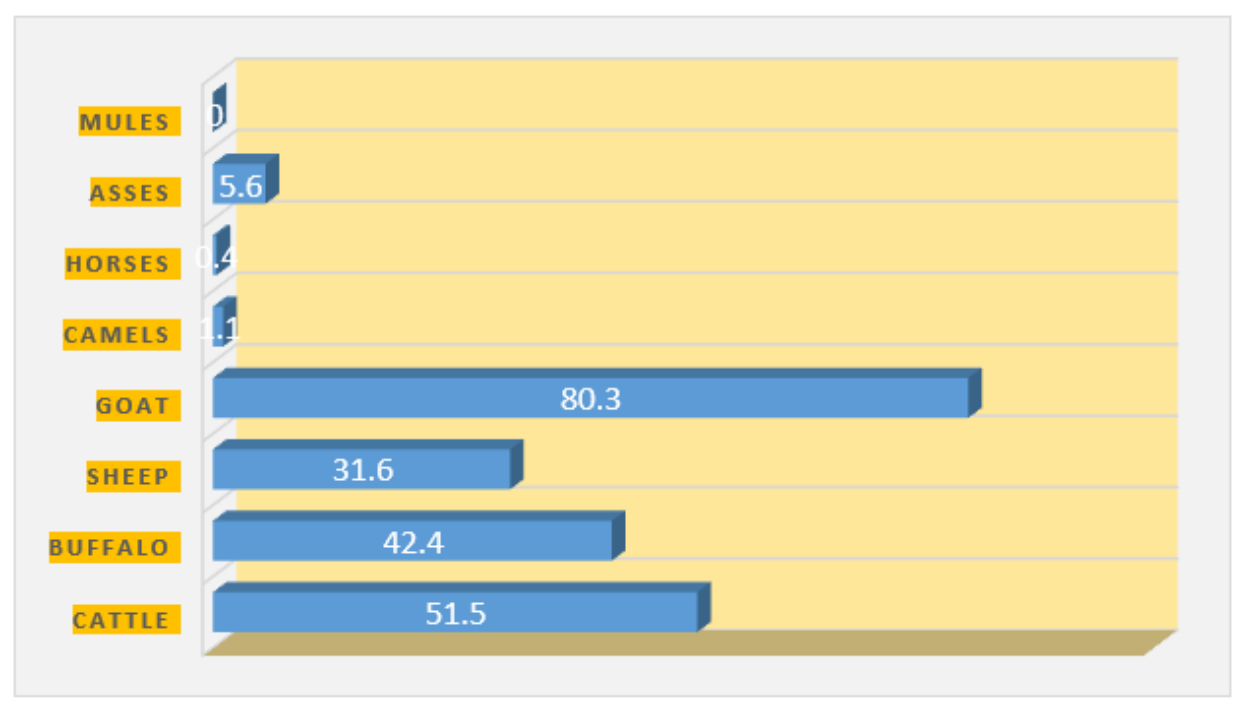

At country level the overall livestock population is estimated to be $80.3 \%$ goats, $31.6 \%$ sheep's, $42.4 \%$ buffalos, $51.5 \%$ cattle and so forth as shown in figure- 1 during the fiscal years of 2020 and 21 respectively (GoP, 2020-21).

Federal government took a serious action in order to address livestock-productivity as well as improvement of poultry industries so as to increase the per unit animal. Therefore, in this regard the government also promoted the public and private partnership so as to enhance the research and development (R\&D) efforts. Further, livestock marketing has the major promotion place of the livestock farmers. Additionally, the federal government has also promoted the genetic-improvement program in the entire country so as to encourage the animal breeds (GoP, 2020-21).

\subsection{Text rationale}

Livestock sector at Balochistan level contributes to the huge socio-economic impacts as a result the income of the rural people is enhanced. Livestock sector in Balochistan has a huge potential and a salvation section of Balochistan economy. Mainstream rustic individuals in a straight line depend on this sector. But unfortunately at province level this sector faces various problems like the lack of management practices in the livestock sector, very limited chances for livestock farmers to sell or buy their domestic animal at national level, very poor animal health services plus insufficient cold chain distribution arrangements at province level. So, the current investigation was conducted so as to assess livestock's role in the selected district of Balochistan. 


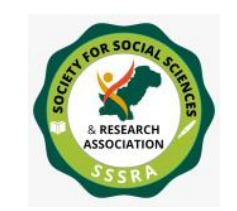

Pak. Journal of Int'L Affairs, Vol 4, Issue 3 (2021) Importance of Livestock Sector for Sustainable ...

\subsection{Investigation objectives}

1. To measure the demographic information of respondents in selected areas or study areas.

2. To assess livestock role within terms of socio-economic attribution in rural areas.

3. To design appropriate or decent recommendations for upcoming strategy implications concerning development of the livestock sector.

\subsection{Methodology selection}

Applied in this study. Quantitative investigation in terms of cross-sectional research design was employed (Babbie \& Mouton, 2004). In this regard, 2 localities or districts were selected. Khuzdar and Zhob localities are randomly selected. On the other hand, 300 respondents were selected. One hundred fifty (150) respondents from each district were selected by using cluster sampling (Cohen et al., 2000). A well questionnaire was developed. All selected respondents interviewed concerning the livestock sector role at Balochistan level. Questionnaires contained various concepts regarding livestock role and so forth (Trochim, 2000). Sample size from a given population, the Krejcie and Morgan (1970) statistical table was used. Cronbach ${ }^{\text {ee }}$ A Alpha program was imperative aspects this study (Gay \& Mills, 2006; and Nunnally \& Bernstein, 1994). However, the ranges were noted as .87 to .83 (Nunnally, 1967; and Nunnally 1978). In this research both constructs were used like independent and dependent variables (Ary et al., 1996). Raw Dara was broken down by using the Statistical Package for Social Science (George \& Mallery, 2003). Pearson Chi-square test applied as the non-parametric test (Chi-square test, 2014; and Cohen et al., 2000). P-value based on 5 levels was set, however, both independent and dependent variables were applied (Leedy, 1989).

\subsection{Findings}

Demographic information's was measured by using the graphics. The data was gathered at field of the livestock farmers. However, on the other hand, the general information was analyzing by using the Pearson Chi-square.

Figure-2, Demographic information about age of the respondents 
Pak. Journal of Int'L Affairs, Vol 4, Issue 3 (2021) Importance of Livestock Sector for Sustainable ..

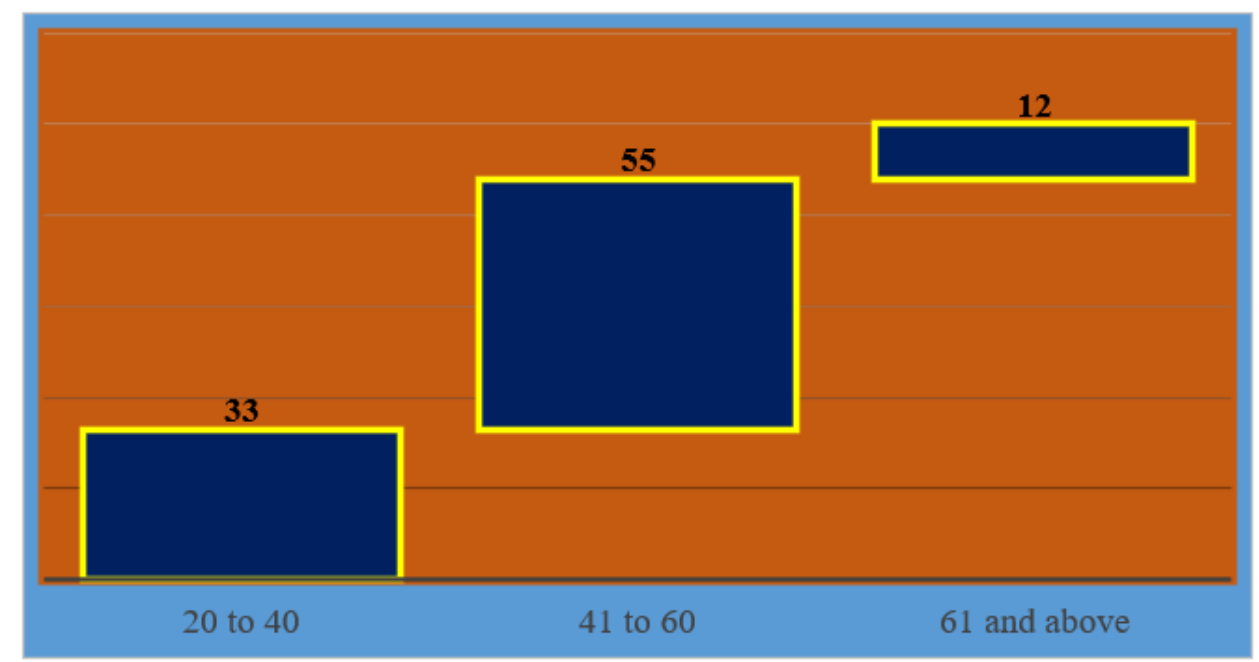

The age variables were measured by using the simple mean as shown in figure- 2 . More than half $(55 \%)$ of the respondents fell into the 41 to 60 years' age categories. While $33 \%$ of the respondents fell into the 20 to 40 years' age categories. However, fraction numbers $(12 \%)$ of the respondents were 61 and above years.

\section{Figure-3, Demographic information about educational level of the respondents}

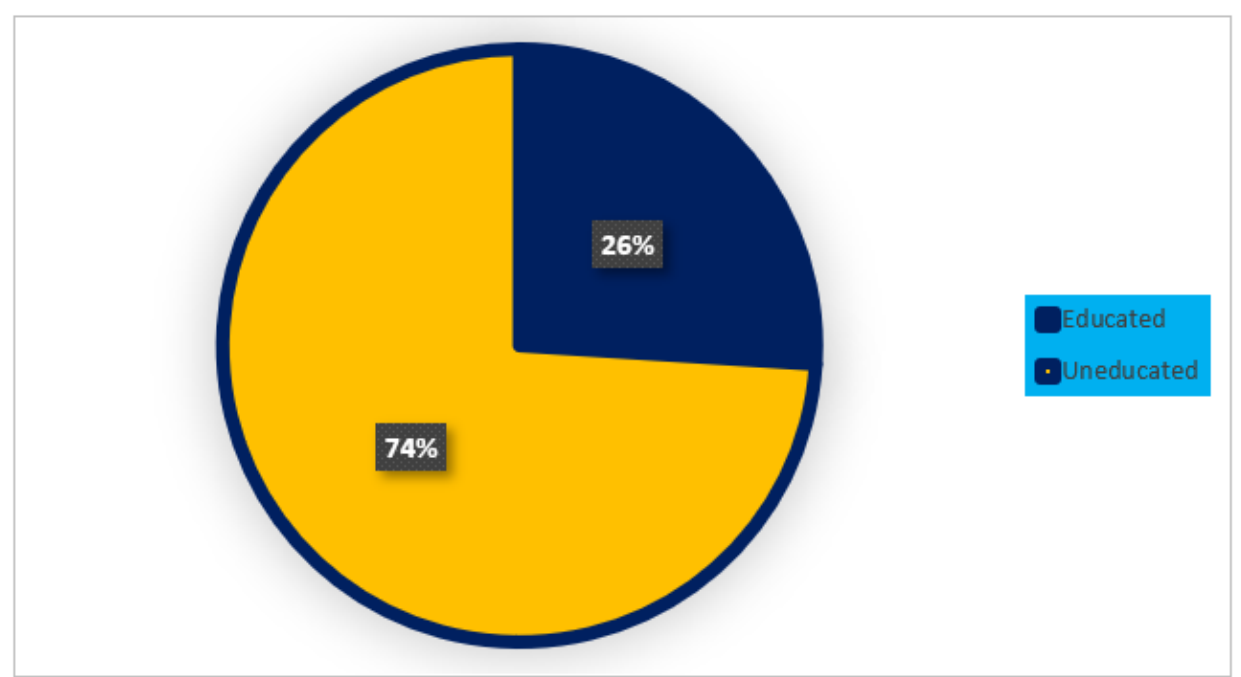

Education segments of the respondents were the imperative aspects in this research. Keeping in view study objectives the educational level as an independent variable were 
Pak. Journal of Int'L Affairs, Vol 4, Issue 3 (2021) Importance of Livestock Sector for Sustainable ...

measured. The result of figure-3 was that the vast majority of the respondents were illiterate $(74 \%)$. Whereas $26 \%$ of the respondents were literate or educated in the selected district of Balochistan.

\section{Figure-4, Demographic information about gender}

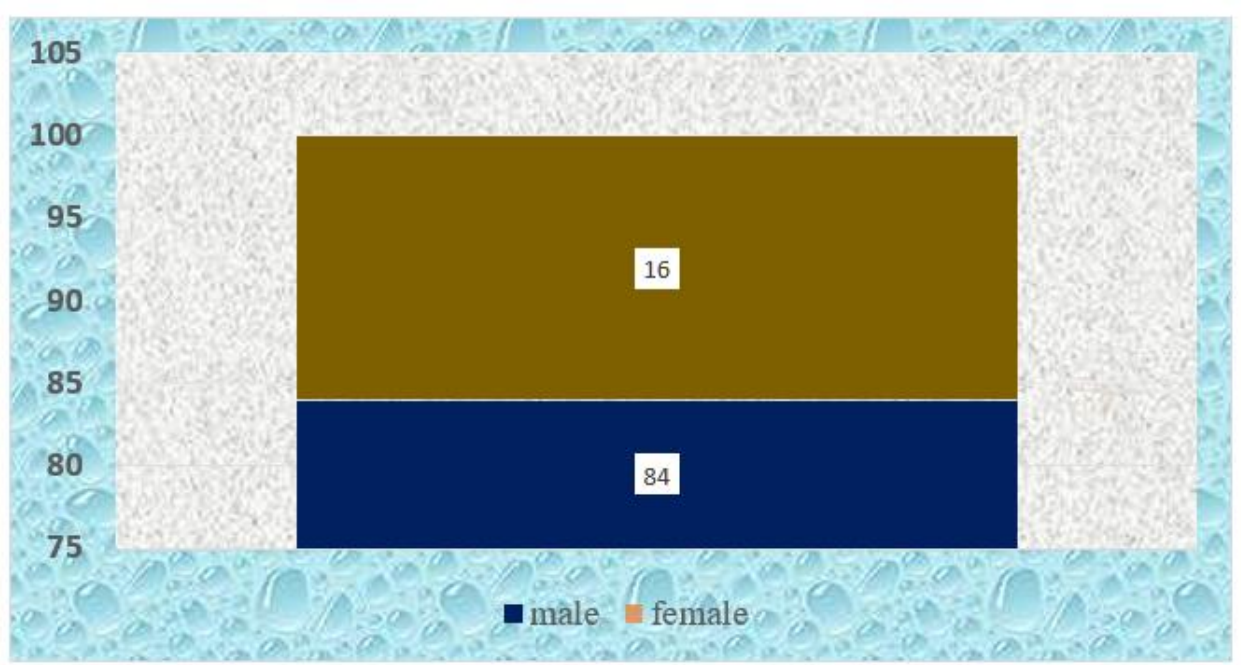

Gender is the vital independent variable as shown in figure-4. However, both male and female have played vital roles in livestock management in both selected districts at provincial level. Majority $(84 \%)$ of the respondents was by gender male, while the remaining $16 \%$ of the respondents were female.

Figure-5, Demographic information about family structure

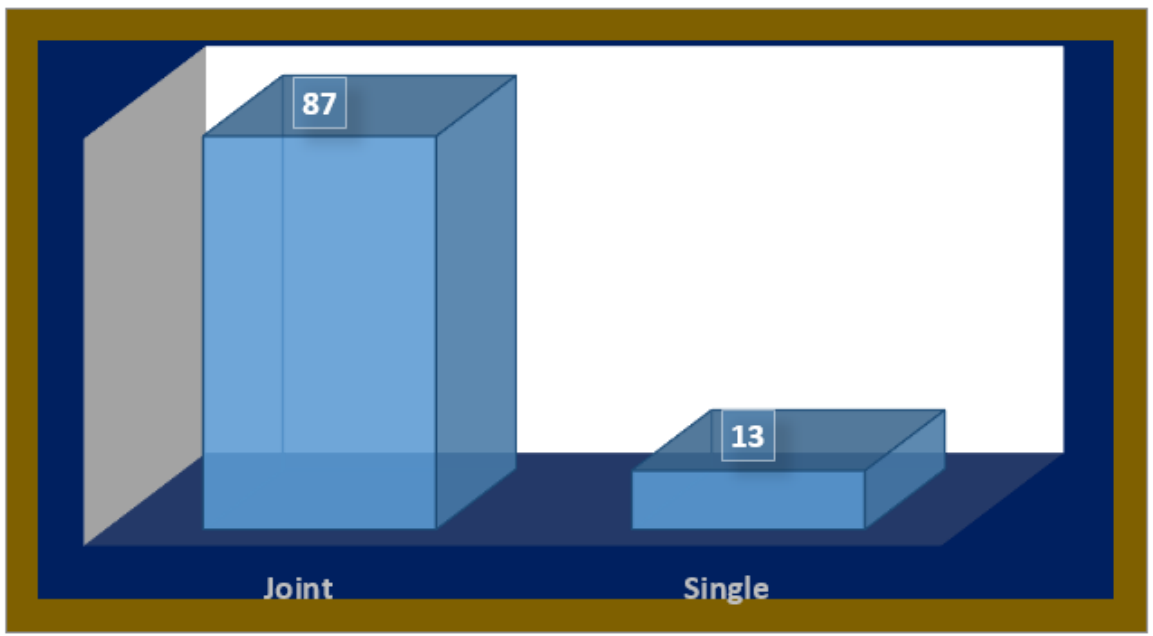


In Pakistan the family plays a vital role in rural areas. Majority of the rural people lived to join the joint family system due to their unique socio-economic system. In this regard the data was gathered at field level. Majority $(87 \%)$ of the respondents preferred to live in a joint family system. While only $13 \%$ of the respondents lived in a single family system (figure-5).

Table-1, Importance of livestock perceived score by using the Crosstabs

\begin{tabular}{|l|c|c|c|}
\hline $\begin{array}{l}\text { Importance of livestock sector in } \\
\text { selected district of Balochistan }\end{array}$ & Value & \multicolumn{1}{|l|}{ df } & $\begin{array}{c}\text { Asymp: Sig. (2- } \\
\text { sided) }\end{array}$ \\
\hline Khuzdar district livestock respondents & \multicolumn{5}{|l|}{} \\
\hline Pearson Chi-Square & $2.951^{\text {a }}$ & 4 & $\mathbf{. 5 6 6 N A}$ \\
\hline Likelihood Ratio & 3.048 & 4 & .550 \\
\hline Linear-by-Linear Association & .517 & 1 & .472 \\
\hline Phi & .099 & - & .566 \\
\hline Cramer's V & .099 & - & .566 \\
\hline Zhob/district livestock respondents & $22.075^{\mathrm{a}}$ & 4 & $.000^{* *}$ \\
\hline Pearson Chi-Square & 23.557 & 4 & .000 \\
\hline Likelihood Ratio & 5.008 & 1 & .025 \\
\hline Linear-by-Linear Association & .271 & - & .000 \\
\hline Phi & .271 & - & .000 \\
\hline Cramer's V & & \\
\hline $\begin{array}{l}\text { No. of Valid Cases = "300" respondents } \\
\text { *Significant at 5\% level }\end{array}$
\end{tabular}

Livestock farmers were inquired regarding the importance of livestock in Balochistan. In this context, the general information collected at field level as shown in table-1 based on ( $\mathrm{p}$ $\leq 0.05)$ level. Chi-Square technique within terms of cross tabulation was used in this regard to measure the between variables. Highly significant inconsistencies found in Khuzdar and Zhob districts by using the Chi-Square test. However, the Phi as well as Cramer's values were probably measured based on assumption as revived from the respondent. Further, Chi-Square values was exceedingly significant in Zhob district: (Chi-Square=22.075a), 
Pak. Journal of Int'L Affairs, Vol 4, Issue 3 (2021) Importance of Livestock Sector for Sustainable ...

(Likelihood Ratio=23.557) and (Linear-by-Linear Association=5.008) receptively at ( $p$ $\leq 0.05)$ level. Then again, Chi-Square values estimated non-significant in Khuzdar district: $\left(\right.$ Chi-Square $\left.=2.951^{\mathrm{a}}\right)$, $($ Likelihood Ratio=3.048) and $($ Linear-by-Linear Association= .517) receptively. Significant $(p<.05)$ association occurs between the binary variables.

\subsection{Conclusion and solid recommendations}

With the intention of measure, the opinion and views of the respondents about the role and importance of livestock sector current study carried out. In this regard, this sector has consisted of an imperative segment about socio-economic acceleration of rural people. Majority of the remote areas people and their income generation process are directly or indirectly linked with this sector. Following solid recommendations developed keeping in view study results. Vigorous futuristic marketing mechanisms about livestock advancement should be established so that the livestock farmers could easily develop their business. Credit schemes for livestock farmers should be started in order to increase the livelihood options of the rural masses. 
Pak. Journal of Int'L Affairs, Vol 4, Issue 3 (2021) Importance of Livestock Sector for Sustainable ...

\section{REFERENCES}

Ary, D., Jacobs, L. C. \& Razavieh, A. 1996. Introduction to Research Education. (5th Ed.). New York: Holt, Rinehart and Winston, Inc.

Babbie, E. \& Mouton, J. 2004. The practice of social research. Cape Town: Oxford University Press.

Chi-square test, 2014. Retrieved from June 12, 2014, from www.21v.Psu. edu/ixm57/chisquar.html.

Cohen L, Menion L, and Morrison, 2000. Research Methodology in Education. (5th ed.). London: Routledledge.

Cohen L, Menion L, and Morrison, 2000. Research Methodology in Education. (5th ed.). London: Routledledge.

Gay, L. R., \& Mills G. E. 2006. Educational Research: Competencies for Analysis and Applications5th ed. Upper Saddle River, N.J.: Merrill/Prentice Hall.

George, D. \& Mallery, P. 2003. SPSS for Windows step by step: A simple guide and reference: 11.0 update (4th Ed.). Boston: Allyn \& Bacon.

GoP, 2020-21. Livestock and Poultry sector. Economic Survey of Pakistan. Economic Advisory Wing, Finance Division, Islamabad.

GoP, 2021. Livestock and Poultry. Agriculture section. Pakistan Economic Survey 202021.

Krejcie, R.V., \& Morgan, D.W. 1970. Determining sample size for research activities . Educational and psychological measurement, 30, 607-610. Retrieved from http://home.kku.ac.th/sompong/guest.

Leedy, P., D. 1989. Practical research (4th ed.): New York: Macmillan Publishing Company, USA.

Nunnally, J. C. 1967. Psychometric theory. New York: McGraw-Hill.

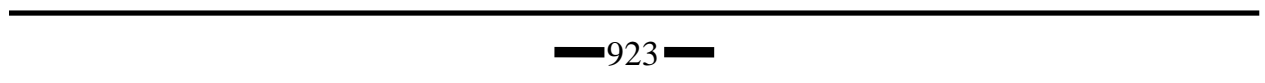


Nunnally, J. C. 1978. Psychometric Theory (2nd Ed.). New York: McGraw-Hill Book Company

Nunnally, J.C., \& Bernstein, I. H. 1994. Psychometric theory (3rd Ed.) New York: McGraw-Hill.

Trochim, W. M. 2000. The Research Methods Knowledge Base, 2nd Edition. Atomic Dog Publishing, Cincinnati, $\mathrm{OH}$. 